\title{
Development of in vitro culture of rat Leydig cells after purification with Nycodenz gradient
}

\author{
Ekayanti Mulyawati Kaiin ${ }^{1^{*}}$, Ita Djuwita ${ }^{2}$, Tuty Laswardi Yusuf ${ }^{3}$, Mohamad Agus Setiadi ${ }^{3}$ \\ ${ }^{1}$ Research Center for Biotechnology, Indonesian Institute of Sciences (LIPI), Cibinong, Indonesia; \\ ${ }^{*}$ Corresponding Author: ekayantikaiin@yahoo.com \\ ${ }^{2}$ Department of Anatomy, Physiology and Pharmacology, Faculty of Veterinary Medicine, Bogor Agriculture University (IPB), \\ Jl. Agatis Kampus Darmaga, Bogor, Indonesia \\ ${ }^{3}$ Department of Veterinary Clinic, Reproduction and Pathology, Faculty of Veterinary Medicine, Bogor Agriculture University (IPB), \\ Jl. Agatis Kampus Darmaga, Bogor, Indonesia
}

Received 11 July 2013; revised 23 August 2013; accepted 12 September 2013

Copyright (C) 2013 Ekayanti Mulyawati Kaiin et al. This is an open access article distributed under the Creative Commons Attribution License, which permits unrestricted use, distribution, and reproduction in any medium, provided the original work is properly cited.

\begin{abstract}
The study examined the effect of human Chorionic Gonadotrophin (hCG) and/or Insulin Transferring Sodium Selenite (ITS) on the proliferation and development of rat Leydig cells purified by Nycodenz gradient. Leydig cells purity, viability and proliferation after purification and 3 days of cultured were evaluated. Leydig cells $1 \times 10^{6}$ cells $/ \mathrm{ml}$ were cultured in DMEM containing $10 \%$ Newborn Calf Serum (NBCS) and divided into four kinds of treatments 1) as a control, 2) control + $2.5 \mathrm{lU} / \mathrm{ml} \mathrm{hCG,} \mathrm{3)} \mathrm{control} \mathrm{+} \mathrm{ITS}(5 \mu \mathrm{g} / \mathrm{ml}$ insulin, $10 \mu \mathrm{g} / \mathrm{ml}$ transferrin, $5 \mu \mathrm{g} / \mathrm{ml} \mathrm{Se}$ ), and 4) control + hCG + ITS. Leydig cells purification results showed $91.40 \%$ of purity, viability was $98.17 \%$ and concentration $7.03 \times 10^{6} \mathrm{cells} / \mathrm{ml}$. The addition of ITS and hCG + ITS in DMEM produced Leydig cell proliferation by $88.35 \%$ and $90.64 \%$ higher than in controls $(86.82 \%)(p<0.05)$. The addition of hCG did not increase Leydig cell proliferation $(86.99 \%)$. In the primary culture of Leydig cells, the population doubling time (PDT) was 1.03 days, similar with the addition of hCG treatment (1.02 day). Declined in value of PDT significantly $(p<0.05)$ occurred in DMEM supplemented with ITS (0.97 day) and hCG + ITS ( 0.88 day). This result was also seen in the first and second Leydig cell lines. DMEM added with hCG or hCG + ITS resulted in a higher amount of testosterone $(5.06 \mathrm{ng} / \mathrm{ml} ; 5.25 \mathrm{ng} / \mathrm{ml}))$ than the culture medium without hCG $(2.46 \mathrm{ng} / \mathrm{ml})(p<$ 0.05 ). It can be concluded that the combination of hCG + ITS can increase the number of Leydig cells and testosterone levels in the culture medium.
\end{abstract}

Keywords: Leydig; In Vitro; Rat; Nycodenz; hCG; ITS; Testosterone

\section{INTRODUCTION}

Androgen hormonal therapy for hypogonadism in men has been done to maintain testosterone level physiologically. Bhasin \& Bremer stated that this therapy can increase muscle strength, improve osteoporosis, stabilized bone density and restore the secondary sexual characters [1]. However, provision of these hormones in the long term can cause an increase in blood viscosity, red blood cell formation abnormalities, hypertension, stroke, bone density changes and emotional changes [1-3]. Therefore, it is necessary to attempt an alternative therapy such as Leydig cells transplantation which naturally produced testosterone that can be used to replace the use of synthetic testosterone hormone [1]. This cellular therapy has limitations in terms of availability of tissue and cells. Therefore, Leydig cell culture is required to obtain a source of cells that will be used in cellular therapy. Testicular tissue consists of somatic cells like Sertoli cells, Leydig cells, fibroblasts, and spermatogenic cells (male gamet cells) in various stages of development, and other cells so it requires to be isolated and purified with appropriated methods like Nycodenz gradient [4]. Nycodenz or Iohexol has several advantages compared to Percoll including lower osmolality and viscosity but higher density. It was able to separate macromolecules and cells effectively with a broader range of sizes for more varied cell types. Nycodenz are stable, soluble in water and can be sterilized with a syringe filter that is easy to use in the laboratory and non cytotoxic against mammalian cells. Additionally, Nycodenz can be easily 
removed from the cell suspension by centrifugation compared with gradients of other materials because the residual gradient can lead to cell death. Nycodenz can be used easily by a simple method without any limitations in temperature, $\mathrm{pH}$ and stability [5]. Nycodenz gradient was used to separate blood cells, liver cells, the primordial germ cell (PGC), spermatogonia and Sertoli cells [6-8].

To obtain an optimum condition in supporting proliferation of Leydig cell culture in vitro, medium culture requires some bioactive materials such as human Choriogenic Gonadotrophin (hCG) and Insulin Transfferin Sodium Selenite (ITS). Leydig cell may secrete several bioactive materials such as peptide, growth hormone, Interleukin-1 (IL-1) and Interleukin-6 (IL-6), testosterone and others to support their growth [9-11]. Luitenizing Hormone $(\mathrm{LH})$ or hCG is necessary for the proliferation and differentiation of Leydig cells so that the cells are able to produce testosterone [12]. The concentration of testosterone in human Leydig cell culture medium has increased after the addition of $1 \mathrm{IU} \mathrm{hCG} / \mathrm{ml}$ [9] whereas the addition of $5 \mathrm{IU}$ hCG on Leydig cell culture medium of young rabbit produce a large amount of testosterone [13]. From several studies before, it seems that addition of ITS is required as a bioactive material for the Leydig cell proliferation. Chemes et al. [9] added transferrin 10 $\mu \mathrm{g} / \mathrm{ml}$ and insulin that can enhance the production of testosterone by the Leydig cells of fetal mice in the culture medium for 24 and 48 hours [14]. Bernier et al. [15] added insulin and transferrin each $5 \mu \mathrm{g} / \mathrm{ml}$ and $1 \mathrm{IU}$ $\mathrm{hCG} / \mathrm{ml}$ into the culture of Leydig cells piglets which causes an increase in the synthesis of testosterone compared to those without addition of hCG. The purpose of this study was to test the influence of the addition of $\mathrm{hCG}$, ITS or in combination in DMEM medium on proliferation and development of Leydig cells and to get an optimum condition of adult rat Leydig cells in vitro.

\section{MATERIALS AND METHODS}

\subsection{Isolation and Purification of Leydig Cells}

Testes were collected from the rats (Sprague Dawley) adult males aged 8 - 10 weeks after anesthetized and sacrificed by cervical dislocation. Testicular tissue was placed in a petri dish contains Dulbecco's Phosphate Buffer Saline (DPBS) without Ca and Mg (Gibco, 21600 - 010, Invitrogen, NY, USA). The tissue was then washed three times using medium DPBS supplemented with 0.1\% Newborn Calf Serum (NBCS, Gibco, 16010 - 159, Invitrogen, New Zealand) (DBPS). Testicular tissue were then put into tubes containing one $\mathrm{ml}$ of $0.04 \%$ collagenase type I (Sigma, C0130, St. Louis, MO, USA) and $10 \mu \mathrm{g} / \mathrm{ml}$ trypsin inhibitor (Sigma, T9003, St. Louis, MO,
USA) in DPBS and incubated in a water bath at a temperature of $34^{\circ} \mathrm{C}$ for $40 \mathrm{~min}$. Cell suspension diluted four times to initial volume with DPBS then allowed to precipitate. Supernatant was collected and centrifuged at $200 \mathrm{~g}$ for three minutes. Cell pellet then was washed twice by using DPBS and diluted with $0.5 \mathrm{ml}$ DPBS. Isolation and purification of Leydig cells were conducted by using Nycodenz gradient. The cell suspension were put into Nycodenz gradient 4\%, 8\%, 10\%, 12\%, 15\% and then were centrifuge using rotor swing (KOKUSAN $\mathrm{H}-26 \mathrm{~F}$ ) at $1500 \mathrm{~g}$ for $10 \mathrm{~min}$. Cell layer formed were collected and washed four times with DPBS and DMEM (Sigma, D5532, St. Louis, MO, USA) supplemented 10\% NBCS and centrifuged at $200 \mathrm{~g}$ for three minutes. Cell pellet was diluted with $0.5 \mathrm{ml}$ DMEM and the cell concentration was calculated using Neubauer haemocytometer.

\subsection{In Vitro Culture and the Production of Leydig Cells}

Leydig cells as $1 \times 10^{6}$ cells $/ \mathrm{ml}$ were placed in a petri dish (Corning, 430 165, NY USA) $35 \times 10$ mm containing DMEM medium supplemented with $10 \%$ NBCS as a control (group 1), with $2.5 \mathrm{IU} / \mathrm{ml}$ hCG (Chorulon, Intervet, EU) (group 2), with $5 \mathrm{mg} / \mathrm{ml}$ insulin, $10 \mathrm{mg} / \mathrm{ml}$ transferrin, $5 \mu \mathrm{g} / \mathrm{ml}$ Se (ITS, Sigma I3146, St Louis, MO, USA) (group 3) and hCG + ITS (group 4). All petri dish then cultured in a $5 \% \mathrm{CO}_{2}$ incubator (Sanyo, MCO-95, Japan) at $37^{\circ} \mathrm{C}$. After cultured for three days, Leydig cells were calculated for their concentration, viability and purity. Leydig cells were stained by Trypan Blue and specific staining 3- $\beta$ HSD. Primary cultures from the each treatment were passage on day 3 and after washing with DPBS medium then the cells were calculated using a Neubauer haemositometer. Cell was then cultured again until reaching a confluent stage. Passage was performed twice and was counted Population Doubling Time (PDT) with the formula:

$$
\begin{aligned}
& \operatorname{PDT}(\text { day }) \\
& =\frac{1}{(\log \text { final cell number }-\log \text { initial cell number }) \times 3.32} \\
& \text { time }
\end{aligned}
$$

\subsection{Testosterone Content from Leydig Cell Culture Medium}

Leydig cell culture medium from each treatment were collected on day 3 and tested by using Testosterone ELISA kit (DRG Diagnostics EIA 1559). Tests were carried out at the Laboratory of Hormones, Reproduction Rehabilitation Unit, Faculty of Veterinary Medicine, Bogor Agriculture University (IPB). 


\subsection{Experimental Design and Data Analysis}

Leydig cell cultures performed three replications for each treatment. The parameters measured were viability, purity, PDT and number of Leydig cells alive. Leydig cell lines made up to second passage and repeated three times. The content of testosterone in the culture medium were conducted three replications in each treatment. Data were analyzed using one way ANOVA and if there is a difference between treatments followed by Duncan's. All cases significance was set at $p<0.05$.

\section{RESULTS}

The results showed that a percentage of Leydig cells after purified with Nycodenz gradients were $91.40 \%$, while the viability was $98.17 \%$ and the cell concentration was $6.30 \times 10^{6}$ cells $/ \mathrm{ml}$ (Table 1).

The effect of hCG, ITS or in combination on Leydig cell proliferation in vitro were presented at Table 2. Leydig cells proliferation were cultured in DMEM + ITS and DMEM + hCG + ITS significantly $(p<0.05)$ higher at $88.35 \%$ and $90.64 \%$ when compared to control $(86.82 \%)$. The addition of hCG to the Leydig cell culture medium did not increase the proliferation of Leydig cells (86.99\%). The percentage of Leydig cells tend to decline at the end of treatment by hCG, ITS and the combination.

The result of the passage of Leydig cells increased in cell number at the end of the primary culture and also at first and second cell lines (Table 3). In between treatments shows that the role of hCG and ITS increased the number of Leydig cells compared with the other treatments.

Table 1. Purity, viability and concentration of Leydig cell after purification with Nycodenz gradient.

\begin{tabular}{lc}
\hline Parameter & Leydig Cells \\
\hline Purity (\%) & $91.40 \pm 5.02$ \\
Viability (\%) & $98.17 \pm 0.51$ \\
Cell concentration $\left(10^{6}\right.$ cells $\left./ \mathrm{ml}\right)$ & $7.03 \pm 1.04$ \\
Number of living cells $\left(10^{6} \mathrm{cells} / \mathrm{ml}\right)$ & 6.30 \\
\hline
\end{tabular}

Table 2. Primary cultures of Leydig cells after purified with Nycodenz gradient.

\begin{tabular}{ccccc}
\hline \multicolumn{5}{c}{ Medium treatment } \\
\hline Parameter & DMEM & $\begin{array}{c}\text { DMEM } \\
+ \text { hCG }\end{array}$ & $\begin{array}{c}\text { DMEM } \\
+ \text { ITS }\end{array}$ & $\begin{array}{c}\text { DMEM + } \\
\text { hCG + ITS }\end{array}$ \\
\hline $\begin{array}{c}\text { Proliferation } \\
\text { rate (\%) }\end{array}$ & $86.82^{\mathrm{a}}$ & $86.99^{\mathrm{a}}$ & $88.35^{\mathrm{b}}$ & $90.64^{\mathrm{c}}$ \\
$\begin{array}{c}\text { Leydig cells (\%) } \\
\text {-Initial culture }\end{array}$ & 90.75 & 90.75 & 90.75 & 90.75 \\
-End of culture & 88.75 & 88.25 & 88.00 & 88.50 \\
\hline
\end{tabular}

Note: Different superscript letters indicate significant differences $(p<0.05)$ by Duncan test on the same line.
Table 3. Number of cells and PDT from cell suspense in vitro.

\begin{tabular}{lccc}
\hline $\begin{array}{l}\text { Cell line in several } \\
\text { medium treatment }\end{array}$ & $\begin{array}{c}\text { Initial cell } \\
\text { number } \\
\left(10^{6} / \mathrm{ml}\right)\end{array}$ & $\begin{array}{c}\text { End of cell } \\
\text { number } \\
\left(10^{6} / \mathrm{ml}\right)\end{array}$ & PDT (day) \\
\hline Primary cultures & 1 & $7.60^{\mathrm{aA}}$ & $1.03^{\mathrm{a}}$ \\
DMEM & 1 & $7.69^{\mathrm{a}}$ & $1.02^{\mathrm{a}}$ \\
DMEM + hCG & 1 & $8.63^{\mathrm{b}}$ & $0.97^{\mathrm{b}}$ \\
DMEM + ITS & 1 & $10.69^{\mathrm{c}}$ & $0.88^{\mathrm{c}}$ \\
DMEM + hCG + ITS & & & \\
1st cell line & 1 & $6.71^{\mathrm{aAB}}$ & $1.09^{\mathrm{a}}$ \\
DMEM & 1 & $7.60^{\mathrm{a}}$ & $1.03^{\mathrm{a}}$ \\
DMEM + hCG & 1 & $8.30^{\mathrm{a}}$ & $0.99^{\mathrm{a}}$ \\
DMEM + ITS & 1 & $13.56^{\mathrm{b}}$ & $0.82^{\mathrm{b}}$ \\
DMEM + hCG + ITS & & & \\
2nd cell line & 1 & $6.28^{\mathrm{aB}}$ & $1.14^{\mathrm{a}}$ \\
DMEM & 1 & $7.27^{\mathrm{ab}}$ & $1.05^{\mathrm{a}}$ \\
DMEM + hCG & 1 & $8.76^{\mathrm{b}}$ & $0.96^{\mathrm{b}}$ \\
DMEM + ITS & 1 & $9.17^{\mathrm{c}}$ & $0.94^{\mathrm{b}}$ \\
DMEM + hCG + ITS & 1 & & \\
\hline
\end{tabular}

Note: Different small superscript letters indicate significant differences $(p<$ 0.05 ) with Duncan test on the same cell lines. Different capital superscript letters indicate significant differences $(p<0.05)$ with Duncan test in the same treatment with the different cell lines.

The percentage of Leydig cells and the viability was seen in all treatments $(80 \%-91 \%)$. The ability of Leydig cells to proliferate seen from the highest number of Leydig cells in the treatment DMEM $+\mathrm{hCG}+$ ITS in primary culture, first and second cell lines compared to other treatments (Table 4).

The addition of ITS, hCG + ITS in DMEM increasing the number of live Leydig cells $(p<0.05)$ in primary cultures $\left(6.68 \times 10^{6} / \mathrm{ml}\right.$ and $8.31 \times 10^{6} / \mathrm{ml}$ cells $)$. Number of live Leydig cells in first and secondary cell lines on all treatments were also increased $(p<0.05)$ compared with controls. Treatment of the same medium in first and second cell lines reduced the number of live Leydig cells ( $p$ $<0.05$ ) compared to primary culture except the treatment of hCG + ITS on the first cell line, the Leydig cells alive increased in number.

Table 5 shows the content of testosterone increased $(p$ $<0.05)$ in medium with hCG and hCG + ITS to 5.06 $\mathrm{ng} / \mathrm{ml}$ and $5.25 \mathrm{ng} / \mathrm{ml}$ than without hCG $(2.46 \mathrm{ng} / \mathrm{ml})$.

\section{DISCUSSION}

Several different methods of purification of Leydig cells have been reported by other researchers. The percentage of Leydig cells purified by Nycodenz gradient in this experiment was higher than Risbridger and Hedger [16] which was $87 \%$. The same result by Yang et al. (2003) was $95 \%$ and also by Kaiin et al. [4] was $92.22 \%$ using Percoll gradient. However, the concentration of Leydig cells purified by Percoll was higher at $15.42 \times 10^{6} \mathrm{cells} / \mathrm{ml}$ [4]. A higher proliferation of Leydig cells was found when 
Table 4. The purity, viability and number of living cells of Leydig cell lines.

\begin{tabular}{|c|c|c|c|c|c|}
\hline $\begin{array}{l}\text { Cell line in several } \\
\text { medium treatment }\end{array}$ & $\begin{array}{l}\text { Cell concentration } \\
\left(\times 10^{6} / \mathrm{ml}\right)\end{array}$ & Leydig cells (\%) & $\begin{array}{l}\text { Number of Leydig } \\
\text { cells }\left(\times 10^{6} / \mathrm{ml}\right)\end{array}$ & Cell Viability (\%) & $\begin{array}{l}\text { Number of live } \\
\text { cells }\left(\times 10^{6} / \mathrm{ml}\right)\end{array}$ \\
\hline \multicolumn{6}{|l|}{ Primary culture } \\
\hline DMEM & $7.60^{\mathrm{aA}}$ & 85.17 & $6.47^{\mathrm{aA}}$ & $88.67^{\mathrm{A}}$ & $5.74^{\mathrm{aA}}$ \\
\hline $\mathrm{DMEM}+\mathrm{hCG}$ & $7.69^{\mathrm{a}}$ & $85.50^{\mathrm{A}}$ & $6.58^{\mathrm{a}}$ & $89.00^{\mathrm{C}}$ & $5.85^{\mathrm{aD}}$ \\
\hline DMEM + ITS & $8.63^{\mathrm{b}}$ & 86.67 & $7.48^{\mathrm{b}}$ & $89.33^{\mathrm{E}}$ & $6.68^{\mathrm{bG}}$ \\
\hline DMEM + hCG + ITS & $10.69^{c}$ & 87.00 & $9.30^{\mathrm{c}}$ & $89.33^{\mathrm{G}}$ & $8.31^{\mathrm{cI}}$ \\
\hline \multicolumn{6}{|l|}{$1^{\text {st }}$ cell line } \\
\hline DMEM & $6.71^{\mathrm{aAB}}$ & 85.67 & $5.74^{\mathrm{aAB}}$ & $86.33^{\mathrm{A}}$ & $4.96^{\mathrm{aB}}$ \\
\hline DMEM + hCG & $7.60^{\mathrm{a}}$ & $85.33^{\mathrm{A}}$ & $6.49^{\mathrm{a}}$ & $84.00^{\mathrm{D}}$ & $5.45^{\mathrm{bE}}$ \\
\hline DMEM + ITS & $8.30^{\mathrm{a}}$ & 86.67 & $7.19^{\mathrm{a}}$ & $87.00^{\mathrm{E}}$ & $6.26^{\mathrm{cH}}$ \\
\hline $\mathrm{DMEM}+\mathrm{hCG}+\mathrm{ITS}$ & $13.56^{\mathrm{b}}$ & 87.33 & $11.84^{\mathrm{b}}$ & $88.33^{\mathrm{G}}$ & $10.46^{\mathrm{dJ}}$ \\
\hline \multicolumn{6}{|l|}{$2^{\text {nd }}$ cell line } \\
\hline DMEM & $6.28^{\mathrm{aB}}$ & 86.67 & $5.44^{\mathrm{aB}}$ & $80.67^{\mathrm{B}}$ & $4.39^{\mathrm{aC}}$ \\
\hline $\mathrm{DMEM}+\mathrm{hCG}$ & $7.27^{\mathrm{ab}}$ & $89.17^{\mathrm{B}}$ & $6.49^{\mathrm{ab}}$ & $81.67^{\mathrm{D}}$ & $5.30^{\mathrm{bF}}$ \\
\hline DMEM + ITS & $8.76^{\mathrm{b}}$ & 90.67 & $7.94^{\mathrm{b}}$ & $82.67^{\mathrm{F}}$ & $6.57^{\mathrm{cH}}$ \\
\hline DMEM + hCG + ITS & $9.17^{\mathrm{c}}$ & 91.17 & $8.36^{\mathrm{c}}$ & $83.33^{\mathrm{H}}$ & $6.97^{\mathrm{cK}}$ \\
\hline
\end{tabular}

Note: Different small superscript letters indicate significant differences $(p<0.05)$ with Duncan test in the same cell line. Different capital superscript letters indicate significant differences $(p<0.05)$ with Duncan test in the same treatment with different cell lines.

Table 5. Testosterone content in Leydig cells culture medium.

\begin{tabular}{llc}
\hline \multicolumn{1}{c}{ Treatment } & n & Testosterone (ng/ml) \\
\hline DMEM + 10\% NBCS (DMEM) & 2 & $1.29^{\mathrm{a}}$ \\
Leydig cells + DMEM & 3 & $2.46^{\mathrm{ab}}$ \\
Leydig cells + DMEM + hCG & 3 & $5.06^{\mathrm{c}}$ \\
Leydig cells + DMEM + ITS & 3 & $3.19^{\mathrm{b}}$ \\
Leydig cells + DMEM + hCG + ITS & 3 & $5.25^{\mathrm{d}}$ \\
\hline
\end{tabular}

Note: The different superscript letters indicate significant difference $(p<$ 0.05 ) in column.

cultured in vitro with ITS. Insulin Transferrin Sodium Selenite (ITS) is the supplement that used to increase cell proliferation. Insulin is a polypeptide hormone that helps the absorption of glucose and amino acids, whereas transferrin is an iron-carrying protein aims to help cell nutrient absorption. Selenium is an essential trace element present in the serum.

Doubling time is the time period required by the cell to make twice of size or the number from the original [18]. The faster of proliferation of the cell made the value of PDT lower. The value of PDT from primary cultures of Leydig cells was 1.03 days and that was equivalent to DMEM + hCG treatment (1.02 day). The value of PDT was significantly $(p<0.05)$ lower in DMEM + ITS treatment (0.97 day) and DMEM + hCG + ITS (0.88 day). Similar results occurred in the first and second cell lines. The results showed that the addition of ITS, as well as hCG + ITS makes Leydig cells require shorter time to achieve a cell number twice. It supports the ITS func- tions as a bioactive material that can increase cell proliferation. Butler [19] states that the time required for the process of cell division in vivo occurs approximately 18 24 hours. After passage, the cell is more homogeneous and able to adapt to the environmental conditions in vitro [20]. Leydig cells in primary culture have a fairly high percentage of purity $(>90 \%)$ and because those in culture were homogeneous, they made the value of PDT near to the time of proliferation in vivo. Leydig cell number on treatment with DMEM decreased in the first and second cell lines $(p<0.05)$, therefore, resulted in a higher PDT from primary culture. Similarly occurred in the other treatment, except in the first cell line, that an increase in the number of cells was occurred in hCG + ITS. The addition of ITS in DMEM led to an increased in the number of Leydig cells at the second cell lines compared to the first lines. In general, a decline in the ability of Leydig cell proliferation occurred after passage twice.

According to Hebert et al. [21], the stimulation of proliferation of rat Leydig cell precursors is influenced by growth factors such as Transforming Growth Factor (TGF- $\alpha$ ) and Insulin-like Growth Factor (IGF-I). In addition, Platelet-derived Growth Factor (PDGF-A) which is secreted by Sertoli cells is also required for proliferation and differentiation of adult Leydig cells. The decrease in the number of live Leydig cells in the first and second cell line is probably influenced by the availability of these growth factors in the culture medium.

Leydig cells in culture have the capacity to secrete testosterone up to 72 hours [22]. Level of testosterone 
produced by isolated adult rat Leydig cells in vitro varies from $0.5 \mathrm{ng}$ up to $150 \mathrm{ng} / 10^{6}$ Leydig cells per hour under $\mathrm{LH} / \mathrm{hCG}$ - stimulated condition [16]. Similar results occurred in Leydig cell piglets cultures [15]. In this experiment, Leydig cells were cultured in DMEM + ITS which had the testosterone levels of $3.19 \mathrm{ng} / \mathrm{ml}$. Pointis et al. [14] stated that the addition of insulin in the culture medium can increase the accumulation of testosterone in fetal mouse Leydig cell cultures. Hormone that stimulates steroidogenesis in Leydig cells is Luiteinizing Hormone (LH) which is secreted by the pituitary. Changes in LH levels in vivo can reflect variations of physiological conditions that can induce morphological changes and the ability of Leydig cells to synthesize and secrete testosterone [22]. The use of hCG which is an analog of $\mathrm{LH}$ that can bind to the same receptor with $\mathrm{LH}$ receptors on Leydig cells [23] resulted in the secretion of testosterone. The addition of hCG to the DMEM increased the secretion of testosterone, whereas ITS increased the cell proliferation that can increase the content of testosterone in the culture medium.

The addition of $10 \%$ NBCS hormone in DMEM medium produced the testosterone content of $1.29 \mathrm{ng} / \mathrm{ml}$. Sedelaar and Isaacs [24] reported that hormone testosterone concentrations between 1.2 and $7.5 \mathrm{ng} / \mathrm{ml}$ were found in bovine serum from newborn to one year old assayed using the RIA method. Serum contains several nutritional components such as fatty acids, cholesterol, T3, insulin, IGF, EGF and androgen [25]. Moreover, the addition of serum is made to provide the hormones that stimulate cell growth and function. Serum provides biomatriks that help the process of attachment and spreading of cells, as well as carrier transport protein hormones, minerals and lipids [26].

It can be concluded that the addition of ITS to the culture medium increased Leydig cell proliferation, whereas addition of hCG increased concentrations of testosterone hormone in the Leydig cell culture medium. The combination of ITS and hCG increased cell proliferation and the concentration of testosterone in Leydig cell culture medium. Further research is needed to increase the number of living cells in the production of Leydig cell line.

\section{REFERENCES}

[1] Chen, G.-R., Ge, R.-S., Lin, H., Dong, L., Sottas, C.M. and Hardy, M.P. (2007) Development of a cryopreservation protocol for Leydig cells. Human Reproduction, 22, 2160-2168.http://dx.doi.org/10.1093/humrep/dem169

[2] Behre, H.M., Kliesch, S., Leifke E., Link T.M. and Nieschlag, E. (1997) Long-term effect of testosterone therapy on bone mineral density in hypogonadal men. Journal of Clinical Endocrinology and Metabolism, 82, 23862390.

[3] Bhasin, S., Singh, A.B., Mac, R.P., Carter, B., Lee, M.I. and Cunningham, G.R. (2003) Managing the risk of prostate disease during testosterone replacement therapy in older men: recommendations for a standardized monitoring plan. Journal of Andrology, 24, 299-311.

[4] Kaiin, E.M., Djuwita, I., Yusuf, T.L. and Setiadi, M.A. (2013) Concentration, purity and viability of Leydig cells after purification using Nycodenz and in vitro culture. Jurnal Kedokteran Hewan FKH Unsiyah (Journal of Veterinary Medicine), 7, 75-80. (in Indonesian language)

[5] Miller, S.R. (2006) Assessment of Nycodenz gradient on enrichment and culture of perinatal porcine spermatogonial stem cell. Thesis (pdf). The Graduate Faculty of North Carolina State University.

[6] Evans, W.H. and Flint, N. (1985) Subfraction of hepatic endosomes in Nycodenz gradients and by free electrophoresis. Biochemistry Journal, 232, 25-32.

[7] Manayagi, T., Kurosawa, R., Ohnuma, K., Ueyama, A., Ito, K. and Takahashi, J. (2003) Purification of mouse primordial germ cells by Nycodenz. Reproduction, 125, 667-675.http://dx.doi.org/10.1530/rep.0.1250667

[8] Nakayama, Y., Yamamoto, T. and Abe, S. (1999) IGF-I, IGF-II and insulin promote differentiation of spermatogonia to primary spermatocytes in organ culture of newt testes. International Journal Development Biology, 43, 343-347.

[9] Chemes, H., Cigorraga, S., Bergada, C., Schteingart, H., Rey, R. and Pellizzari, E. (1992) Isolation of human Leydig cell mesenchymal precursors from patients with the androgen sensitivity syndrome: Testosterone production and response to human chorionic gonadotrophin stimulation in culture. Biology of Reproduction, 46, 793-801. http://dx.doi.org/10.1095/biolreprod46.5.793

[10] Cudicini, C., Lejeune, H., Gomez, E., Bosmans, E., Ballet, F., Saez, J. and Jegou, B. (1997) Human Leydigs cells and Sertoli cells are producers of Interleukin-1 and -6. Journal of Clinical Endocrinology and Metabolism, 82, 1426-1433.http://dx.doi.org/10.1210/jc.82.5.1426

[11] Hu, J., You, S., Li, W., Wang, D., Nagpal, M.L., Mi, Y., Liang, P. and Lin, T. (1998) Expression and regulation of interferon- $\gamma$-inducible protein 10 genes in rat Leydig cells. Endocrinology, 139, 3637-3645.

http://dx.doi.org/10.1210/en.139.8.3637

[12] Saez, J.M. (1994) Leydig Cells: Endocrine, paracrine and autocrine regulation. Endocrine Reviews, 15, 574-626. http://dx.doi.org/10.1210/edrv-15-5-574

[13] El-Sherbiny, A.M., Amin, S.O., Hernandez, C. and Carreau, S. (1994) The immature rabbit testis: Presence of two distinct populations of Leydig cells. World Rabbit Science, 2, 141-146.

[14] Pointis, G., Rao, B., Latreille, M.T. and Cedard, L. (1984) Hormonal regulation of testosteron in short term primary culture of fetal mouse Leydig cells. Journal of Steroid Biochemistry, 20, 525-528. http://dx.doi.org/10.1016/0022-4731(84)90266-8

[15] Bernier, M., Gibb, W., Haour, F., Collu, R., Saez, J. M. and Ducharme, J.R. (1983) Studies with purified immature porcine Leydig cells in primary culture. Biology of Reproduction, 29, 1172-1178. http://dx.doi.org/10.1095/biolreprod29.5.1172 
[16] Risbridger, G.P. and Hedger, M.P. (1992) Adult rat Leydig cell cultures: Minimum requirement for maintenance of luteinizing hormone respon-siveness and testosterone production. Molecular and Cellular Endocrinology, 83, 125-132. http://dx.doi.org/10.1016/0303-7207(92)90153-W

[17] Yang, J.-M., Arnush, M., Chen, Q.-Y., Wu, X.-D., Pang, B. and Jiang, X.-Z. (2003) Cadmium-induced damaged to primary cultures of rat Leydig cells. Reproductive Toxicology, 17, 553-560. http://dx.doi.org/10.1016/S0890-6238(03)00100-X

[18] Mader, S.S. (2000) Human biology. McGraw Hill, Iowa.

[19] Butler, M. (2004) Animal cell culture \& technology. 2nd Edition, Bios Scientific Publisher, Taylor \& Francis Group, London. http://dx.doi.org/10.4324/9780203427835

[20] Freshney, R.I. (2005) Culture of animal cells: A manual of basic technique. John Wiley \& Sons Inc, Hoboken.

[21] Hebert, R., Lejeune, H. and Saez, J.M. (2001) Origin, differentiation and regulation of fetal and adult Leydig cells. Molecular and Cellular Endocrinology, 179, 47-74. http://dx.doi.org/10.1016/S0303-7207(01)00461-0

[22] Browning, J.Y., Heindel, J.J. and Grotjan, Jr. H.E. (1982) Method for primary culture of purified Leydig cells iso- lated from adult rat testes. Journal of Tissue Culture Methods, 7(2), 55-58.

http://dx.doi.org/10.1007/BF01665909

[23] Klinefelter, G.R., Hall, P.F. and Ewing, L.L. (1987) Effect of luteinizing hormone deprivation in situ on steroidogenesis of rat Leydig cells purified by a multistep procedure. Biology of Reproduction, 36, 769-783. http://dx.doi.org/10.1095/biolreprod36.3.769

[24] Renlund, N. (2006) Hormonal and paracrine influences on Leydig cell steroidogenesis Dissertation. Karolinska Institutet, Stockholm.

[25] Seedelaar, J.P.M. and Isaacs, J.T. (2009) Tissue culture media supplemented with $10 \%$ fetal calf serum contains a castrate level of testosterone. Prostate, 69, 1724-1729. http://dx.doi.org/10.1002/pros.21028

[26] Hendlund, T.E. and Miller, G.J. (1994) A serum-free defined medium capable of supporting growth of four established human prostatic carcinoma cell lines. Prostate 24, 221-228. http://dx.doi.org/10.1002/pros.2990240502

[27] Freshney, R.I. 1987. Animal cell culture: A practical approach. IRL Press, Washington. 